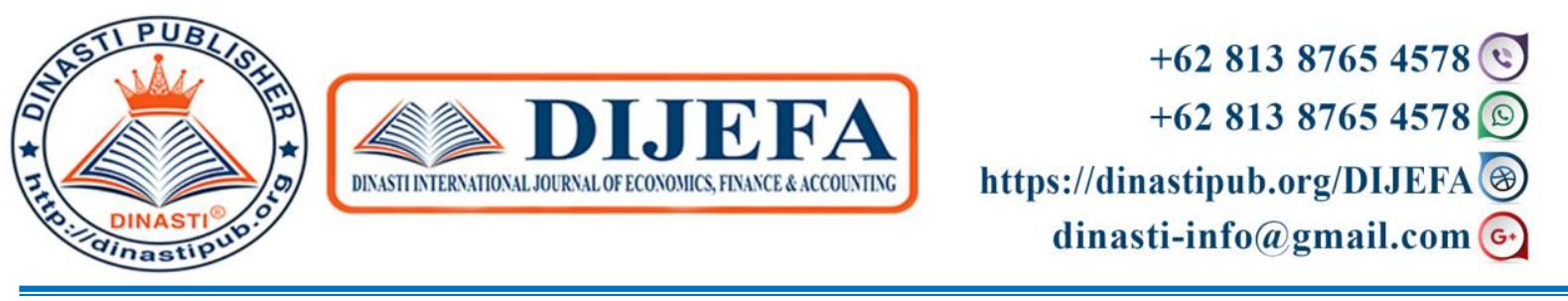

\title{
CONTRACTOR SELECTION ASSESSMENT STRATEGY IN THE UPSTREAM OIL AND GAS INDUSTRY TOWARDS GREEN SUPPLY CHAIN MANAGEMENT
}

\section{Fajar Tri Prasetia ${ }^{1}$, Tukhas Shilul Imaroh ${ }^{2}$}

${ }^{1)}$ Universitas Mercu Buana, Jakarta, Indonesia

${ }^{2)}$ Universitas Mercu Buana, Jakarta, Indonesia

ARTICLE INFORMATION

Received: $20^{\text {th }}$ May 2020

Revised: $20^{\text {th }}$ June 2020

Issued: $7^{\text {th }}$ July 2020

Corresponding author: first author

E-mail:

fajartri.prasetia@yahoo.com tukhas.shilul@mercubuana.ac.id

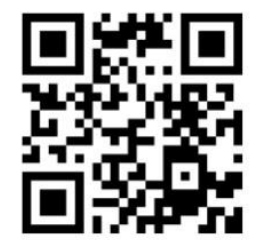

DOI:10.38035/DIJEFA
Abstract: Nowdays, the level of business competition in managing the upstream oil and gas industry is getting higher, therefore oil and gas companies need to improve their performance and optimize the existing resources in the company. This must also be considered in efforts to manage and save the environment, which is currently the main focus of governments and businesses to preserve the environment. In addition to internal improvements were made, improvements are also needed on the part of contractors/suppliers to support this. In this regard, this study was conducted to develop a strategy for conducting an assessment in the contractors selection/suppliers in the upstream oil and gas industry with the aim of implementing Green Supply Chain Management with the Analytic Hierarchy Process (AHP) method. This study maps the evaluation criteria and sub-criteria in the contractors selection and obtains the main criteria in the contractors selection for the upstream oil and gas industry towards Green Supply Chain Management. Results of the study obtain 6 criteria and 23 evaluation criteria in the contractors selection in the upstream oil and gas industry towards Green Supply Chain Management. The two most important criteria obtained are the Environmental criteria and the Health and Safety criteria, both of which have an assessment weight of more than $50 \%$ of the total assessment weight. The next criteria obtained are the Quality (Technical), Technical (Shipping), and Price (Quality) criteria, where these criteria are taken into account in the selection of contractors for the upstream oil and gas industry towards Green Supply Chain Management, so that the spirit of competition remains with the contractor and companies have many options contractor to achieve Green Supply Chain Management.

Keywords: Analytic Hierarchy Process (AHP), contractors/suppliers selection

\section{INTRODUCTION}

The upstream oil and gas industry is progressing and developing, resulting in increased competition between the Oil and Gas Company and their supporting contractors. The high demand from upstream oil and gas companies forced oil and gas service contractors 
to provide optimal and quality services so that it is proportional to the costs incurred by upstream Oil and Gas Company.

The business chain in the upstream oil and gas industry has a high risk of accidents and failures. Accidents and failures in oil and gas operations have caused externalities in the form of environmental pollution, property losses and also human lives. So it must be ensured that the entire oil and gas operation chain runs safely, and environmentally friendly. Supply chain management plays a strategic role in the industry, including the upstream oil and gas industry.

The fact that the upstream oil and gas industrial sector can cause environmental damage, it is necessary to minimize the wrong events by implementing an environmentally friendly system for supply chains in the oil and gas industry, namely Green Supply Chain Management (GSCM). By implementing GSCM, it will have a positive impact on the company by increasing the company's competitiveness, enhancing its brand image for environmental management, and strategic marketing for the industry.

XYZ Company is a company engaged in oil and gas exploration and exploitation. The operational area is in the offshore area of East Kalimantan (Makassar Strait). If refers to the Environmental Safety and Health (K3L) data from XYZ company for the last 4 years, there are still environmental pollution. XYZ Company already has an environmental certification, namely ISO 14001, but in the procurement process at XYZ Company, the criteria and subcriteria for the selection of contractors with the GSCM concept have not been applied. The criteria used so far in the selection of contractors are (a) personnel and experience, (b) engineering and SOP, (c) quality and facilities, and (e) price.

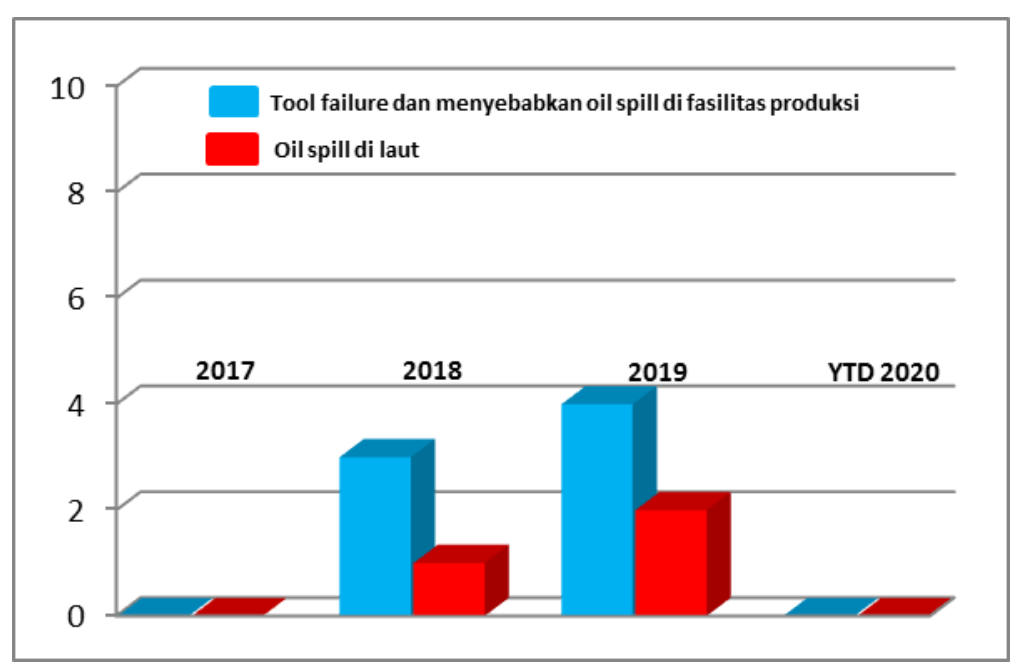

Figure 1. Graph of environmental pollution XYZ company in period 2017 to 2020 (source: XYZ company's internal, 2020)

Taking into account some of the events associated with environmental pollution at XYZ Company, it is necessary to incorporate the concept of Green Procurement in the procurement process. Green Procurement is one of the solutions for the environment and conservative economy of the business and the concept of obtaining a choice of products and services that minimize environmental impact [1]. Therefore, in making the decision to choose the contractors towards GSCM related criteria and sub-criteria, it would be required an effective technique and can give accurate results. 
One method that can be used for multi-criteria decision making is the Analytic Hierarchy Process (AHP). AHP method is a form of selection decisions that allows the users to form opinions and provide limits to the problem through perception or conjecture and produce the desired problem resolution [2].

\section{LITERATURE REVIEW}

\section{Supply Chain Management}

Supply chain is the entire network (from suppliers to end users) that has activities related to the flow and transformation of goods, products, information and money [3]. Supply Chain Management (SCM) is a management activity that aims to obtain raw materials, transform raw materials to become semi-finished or finished goods and distribute these goods to the hands of consumers [2]. The main principle in Supply Chain Management is sharing of material flow, information flow which incorporates all the elements in the supply chain.

\section{Green Supply Chain Management}

Green Supply Chain Management as a process of using environmentally friendly inputs and converting inputs into outputs that can be reused at the end of the cycle so as to create a sustainable supply chain [1]. Green supply chain management is important to implement because so far the size of supply chain performance usually does not pay attention to the impact on the environment.

\section{Difference between Supply Chain Management and Green Supply Chain Management}

Following are the different characteristics between Supply Chain Management and Green Supply Chain Management [4].

Table 1. Difference between SCM and GSCM

\begin{tabular}{|c|l|l|l|}
\hline No & Characteristics & Supply Chain Management & $\begin{array}{c}\text { Green Supply Chain } \\
\text { Management }\end{array}$ \\
\hline 1 & Goals & $\begin{array}{l}\text { Concentrate on economic } \\
\text { goals and values. }\end{array}$ & Ecological and economic \\
\hline 2 & $\begin{array}{l}\text { Ecological } \\
\text { Optimization }\end{array}$ & $\begin{array}{l}\text { Integrated approach } \\
\text { Low ecological impact }\end{array}$ & High ecological impact \\
\hline 3 & $\begin{array}{l}\text { Supplier } \\
\text { Selection } \\
\text { Criteria }\end{array}$ & $\begin{array}{l}\text { Suppliers who offer low } \\
\text { prices are directly selected } \\
\text { Short-term relationship }\end{array}$ & $\begin{array}{l}\text { Ecological aspects } \\
\text { Long-term relationship }\end{array}$ \\
\hline 4 & Pressure on costs & Low & High \\
\hline 5 & Flexibility & High & Low \\
\hline 6 & Quickness & High & Low \\
\hline
\end{tabular}

\section{Method of Procurement Process in the Upstream Oil and Gas Industry}

According to SKK Migas regulations, namely PTK-007 Revision-IV / PTK / 2017 that regulates the Implementation Guidelines for Procurement of Goods and Services [5], there are several methods of procurement processes can be performed in the upstream oil and gas industry, which are:

a) Open Tender 
This is a procurement of goods or services that is done openly to the public and announced in the official announcement of oil and gas companies, print media or electronic media. The open tender method refers to the basic principles of supply chain management.

b) Limited Tender

Limited tender is carried out by inviting at least 2 (two) candidates who meet certain criteria in accordance with PTK 007 regulations and internal company regulation.

c) Direct Tender

It is a method of implementing goods procurement by inviting at least 3 (three) required goods supply companies.

d) Direct Appointment

This is a method of procurement by direct appointment to 1 (one) supplier of the goods needed.

e) Procard

This card is an abbreviation for Procurement card. The method is the procurement of goods or services carried out by direct appointment and by using procard media. This media Procard is used as a means of payment without the need for an agreement, or purchase order.

f) Electronic procurement

This method is done using electronic network facilities (internet or intranet) or electronic data interchange (EDI).

g) Self-Management

The implementation of self-management can be authorized to government agencies, scientific institutions, universities, community groups or national Non-Governmental Organizations (NGOs). Self-management itself is a work whose implementation is planned and carried out by using its own personnel and equipment and supervised by itself or the implementation can be authorized to other parties.

\section{Analytical Hierarchy Process (AHP)}

AHP is a measurement theory through pairwise comparisons and relies on expert judgment to reduce priority scale [6]. In other words, this method is considered a multiobjective-multi-criteria model.

The steps in the AHP method are:

Stage 1: Comparing between criteria or sub-criteria using a predetermined comparison scale. In this case, the comparison scale used is the 9 point comparison Saaty's scale [7]. The goal is to see a picture of the relative importance of one element to other elements by using a pairwise comparison scale.

Stage 2: Make a normalized matrix by dividing the values of each paired matrix cells by the total of each column.

The value of criteria and sub-criteria weights is obtained by dividing the total normalized value of all criteria by the total criteria.

$$
\text { Normalization value }=\frac{a_{i j}}{\sum_{i=1}^{n} a_{i j}}
$$


At this stage, a consistency test of each criteria or sub-criteria is needed to see whether each criteria or sub-criteria is consistent.

Stage 3: Make a paired matrix multiplied by the weight of each criterion.

At this stage, determine the Eigen vector and calculate the $\lambda$ max value.

$$
\lambda_{\text {maks }}=\frac{\text { Eigenvector }}{n}
$$

Stage 4: Calculate Consistency Index (CI)

Calculation of Consistency Index (CI) using the formula:

$$
\mathrm{CI}=\frac{\lambda \mathrm{maks}-\mathrm{n}}{\mathrm{n}-1}
$$

The assessment will be stated with $100 \%$ consistency if $\mathrm{CI}=0$. If $\mathrm{CI} \leq 0.1$, then the assessment is declared acceptable. However, if the CI $\geq 0.1$, the assessment process must be repeated.

Stage 5: Calculate Consistency Ratio (CR)

Calculation of Consistency Ratio (CR) using the formula:

$$
\mathrm{CR}=\frac{C I}{R I}
$$

Random Index (RI) value is obtained by using the formula:

$$
R I=\frac{1.98(n-2)}{n}
$$

Where the value of $\mathrm{n}$ is the number of criteria / sub-criteria used.

Consistency Ratio is a number that shows the level of consistency of a value. If the CR value is $\leq 0.1$, it can still be tolerated. However, if the $C R$ value is $\geq 0.1$, a revision needs to be done. For the value of $\mathrm{CR}=0$, it can be interpreted as "perfectly consistent". [7]

Stage 6: Add up the relative weights and synthesize for the final measurements of the alternative decisions given.

\section{RESEARCH METHODS}

In this study, the AHP method is used to assess the importance of each criteria and sub-criteria that have been selected and then submitted to respondents. List of respondents consisted of 5 expert respondents in the XYZ company. Respondent selection is based on (1) Respondents or experts having work experience of more than 15 years in the procurement and evaluation process for contractor selection, and (2) Respondents or experts always take part in the evaluation process of contractors in the upstream oil and gas sector at XYZ company.

Table 2. List of Respondent

\begin{tabular}{|c|l|c|}
\hline No & \multicolumn{1}{|c|}{ Position } & Experience \\
\hline 1 & $\begin{array}{l}\text { Local Content Manager } \\
\text { Procurement }\end{array}$ & 15 years \\
\hline 2 & Environment Manager & 20 years \\
\hline
\end{tabular}




\begin{tabular}{|c|l|c|}
3 & $\begin{array}{l}\text { Drilling Procurement Team } \\
\text { Leader }\end{array}$ & 15 years \\
\hline 4 & $\begin{array}{l}\text { Sr. Contract Admin for } \\
\text { Drilling operation }\end{array}$ & 20 years \\
\hline 5 & Sr. Operation Geologist & 18 years \\
\hline
\end{tabular}

Below are the steps in the process of assessing criteria and sub-criteria using the AHP method as follows:

a) The criteria and sub-criteria selected were obtained from various references, namely internal company regulations, PTK-007 Revision-IV / PTK / 2017 manual book [5], and PTK-005 Revision-II / PTK / 2018 manual book [8]. These criteria and subcriteria are then submitted to respondents in the criteria and sub-criteria selection questionnaire (stage 1 questionnaire). In this questionnaire using a Likert's scale [9].

b) From the criteria and sub-criteria that have been selected from questionnaire stage 1, then a decision making hierarchy model is made.

c) Do pairwise comparison matrix for the criteria and sub-criteria using the 9 point Saaty's scale (questionnaire stage 2).

d) Calculate weights and consistency test using expert choice software to get the final synthesis value and the decision making hierarchy model.

The results of the final synthesis and the decision making hierarchy model are taken into consideration in the submission of conclusions and suggestions.

\section{RESEARCH RESULT AND DISCUSSION}

\section{Analysis of the results of weighting criteria}

From the results of the questionnaire stage 1 using Likert's scale is obtained there are 6 (six) main criteria and 23 (twenty three) sub criteria selected as in Table 4.1 below.

Table 3. Main criteria and sub criteria in assessment of contractor selection

\begin{tabular}{|c|c|c|c|}
\hline No & $\begin{array}{l}\text { Contractor } \\
\text { Selection } \\
\text { Assessment } \\
\text { Criteria }\end{array}$ & No & Contractor Selection Assessment Sub criteria \\
\hline \multirow{3}{*}{1} & \multirow{3}{*}{ Price } & 1 & Price consistency \\
\hline & & 2 & Price competitive \\
\hline & & 3 & Price breakdown \\
\hline \multirow{4}{*}{2} & \multirow{4}{*}{ Quality } & 4 & Guarantee \\
\hline & & 5 & ISO 9001 certification \\
\hline & & 6 & Durability product \\
\hline & & 7 & As per specifications \\
\hline \multirow{3}{*}{3} & \multirow{3}{*}{ Delivery } & 8 & $\begin{array}{l}\text { The accuracy of the quantity and type of goods } \\
\text { delivered }\end{array}$ \\
\hline & & 9 & On time delivery \\
\hline & & 10 & Goods received in good condition \\
\hline \multirow{4}{*}{4} & \multirow{4}{*}{ Technical } & 11 & Operational and maintenance support \\
\hline & & 12 & Responsiveness \\
\hline & & 13 & Local Content (TKDN) \\
\hline & & 14 & As per standard \\
\hline 5 & Health and Safety & 15 & Contractor Safety Management System \\
\hline
\end{tabular}




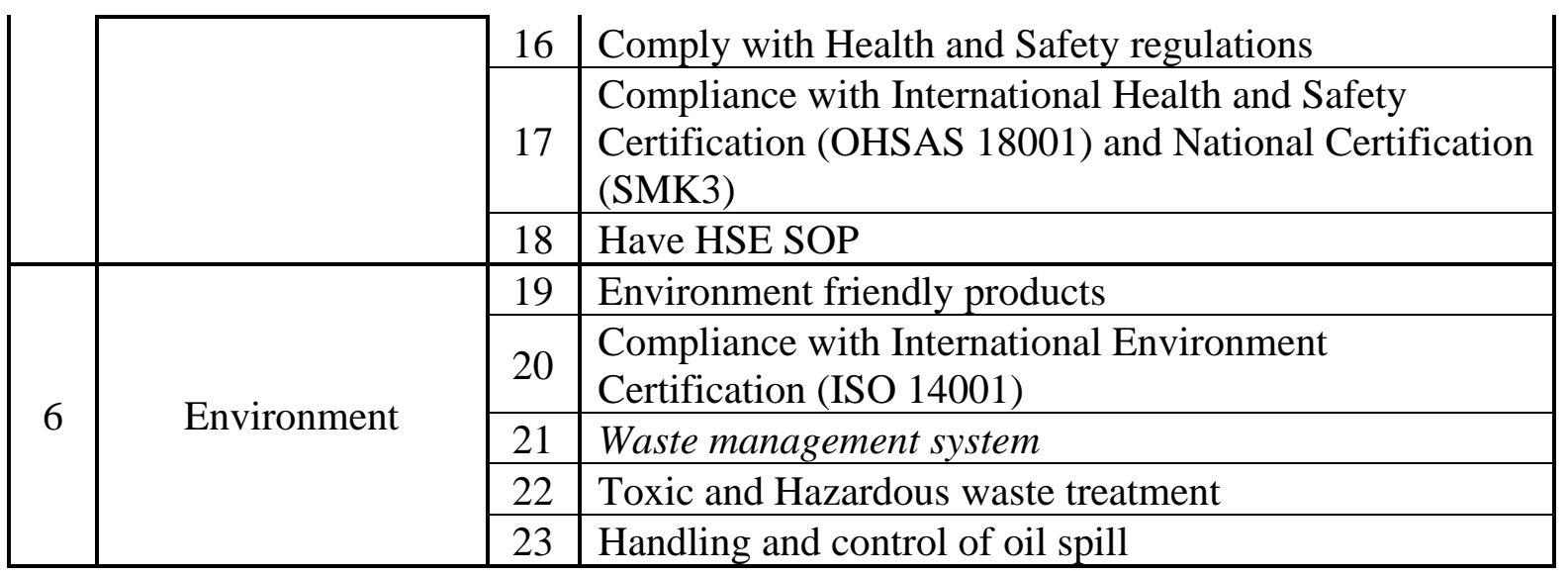

Then pairwise comparison were performed on the questionnaire stage 2 using the 9 point Saaty's scale and processed using expert choice software. Table 4 shows the results of weighting of the questionnaire stage 2 for main criteria.

Table 4. Weight comparison of the main criteria for contractor evaluation

\begin{tabular}{|c|l|c|c|}
\hline No & \multicolumn{1}{|c|}{ Criteria } & Weight & Priority \\
\hline 1 & Environment & 0.366 & I \\
\hline 2 & Health and Safety & 0.360 & II \\
\hline 3 & Quality & 0.093 & III \\
\hline 4 & Technical & 0.092 & IV \\
\hline 5 & Delivery & 0.057 & V \\
\hline 6 & Price & 0.033 & IV \\
\hline
\end{tabular}

From table 4 above shows that in the process of evaluating contractors in the upstream oil and gas industry towards Green Supply Chain Management, the environmental criteria have the highest weighting value of 0.366 , then followed in succession namely the Health and Safety criteria (0.360), Quality criteria ( 0.093), Technical criteria (0.092), Shipping criteria (0.057), and Price criteria (0.33). Environmental Criteria and Health and Safety criteria have a total weight of 0.729 (more than 0.5) and these two criteria are priorities in the assessment of contractors in the upstream oil and gas industry towards Green Supply Chain Management.

\section{Analysis of the results of weighting sub-criteria}

From the results of the questionnaire stage 1, there were 23 sub-criteria identified and then do pairwise comparison of each of the sub-criteria in the questionnaire stage 2 used a 9 point Saaty's scale. The results of the questionnaire stage 2 were processed using expert choice software. Table 5 below shows the results of the weighting of the questionnaire stage 2 for sub-criteria.

Table 5. Weight comparison of the sub-criteria for contractor evaluation

\begin{tabular}{|c|c|c|c|c|}
\hline $\begin{array}{l}\text { Criteria } \\
\text { Priority }\end{array}$ & $\begin{array}{c}\text { Contractor Selection } \\
\text { Assessment Criteria }\end{array}$ & $\begin{array}{c}\text { Contractor Selection } \\
\text { Assessment Sub Criteria }\end{array}$ & Weight & $\begin{array}{c}\text { Sub } \\
\text { Criteria } \\
\text { Priority }\end{array}$ \\
\hline
\end{tabular}




\begin{tabular}{|c|c|c|c|c|}
\hline \multirow{5}{*}{1} & \multirow{5}{*}{ Environment } & $\begin{array}{l}\text { Compliance with International } \\
\text { Environment Certification } \\
\text { (ISO 14001) }\end{array}$ & 0.216 & $\mathrm{I}$ \\
\hline & & $\begin{array}{l}\text { Handling and control of oil } \\
\text { spill }\end{array}$ & 0.208 & II \\
\hline & & Waste management system & 0.200 & III \\
\hline & & $\begin{array}{l}\text { Toxic and Hazardous waste } \\
\text { treatment }\end{array}$ & 0.200 & IV \\
\hline & & Environment friendly products & 0.176 & $\mathrm{~V}$ \\
\hline \multirow{4}{*}{2} & \multirow{4}{*}{ Health and Safety } & $\begin{array}{l}\text { Comply with Health and } \\
\text { Safety regulations }\end{array}$ & 0.352 & I \\
\hline & & $\begin{array}{l}\text { Compliance with International } \\
\text { Health and Safety Certification } \\
\text { (OHSAS 18001) and National } \\
\text { Certification (SMK3) }\end{array}$ & 0.284 & II \\
\hline & & $\begin{array}{l}\text { Contractor Safety } \\
\text { Management System }\end{array}$ & 0.189 & III \\
\hline & & Have HSE SOP & 0.175 & IV \\
\hline \multirow{4}{*}{3} & \multirow{4}{*}{ Quality } & As per specifications & 0.346 & $\mathrm{I}$ \\
\hline & & Guarantee & 0.318 & II \\
\hline & & Durability product & 0.217 & III \\
\hline & & ISO 9001 certification & 0.119 & IV \\
\hline \multirow{4}{*}{4} & \multirow{4}{*}{ Technical } & Responsiveness & 0.295 & $\mathrm{I}$ \\
\hline & & As per standard & 0.287 & II \\
\hline & & $\begin{array}{l}\text { Operational and maintenance } \\
\text { support }\end{array}$ & 0.279 & III \\
\hline & & Local Content (TKDN) & 0.138 & IV \\
\hline \multirow{3}{*}{5} & \multirow{3}{*}{ Delivery } & On time delivery & 0.355 & I \\
\hline & & $\begin{array}{l}\text { The accuracy of the quantity } \\
\text { and type of goods delivered }\end{array}$ & 0.353 & II \\
\hline & & $\begin{array}{l}\text { Goods received in good } \\
\text { condition }\end{array}$ & 0.292 & III \\
\hline \multirow{3}{*}{6} & \multirow{3}{*}{ Price } & Price competitive & 0.598 & $\mathrm{I}$ \\
\hline & & Price breakdown & 0.233 & II \\
\hline & & Price consistency & 0.169 & III \\
\hline
\end{tabular}

\section{Discussion}

Figure 2. below shows the local weights and global weights of the criteria and subcriteria for evaluating the selection of contractors in the upstream oil and gas industry towards Green Supply Chain Management. 


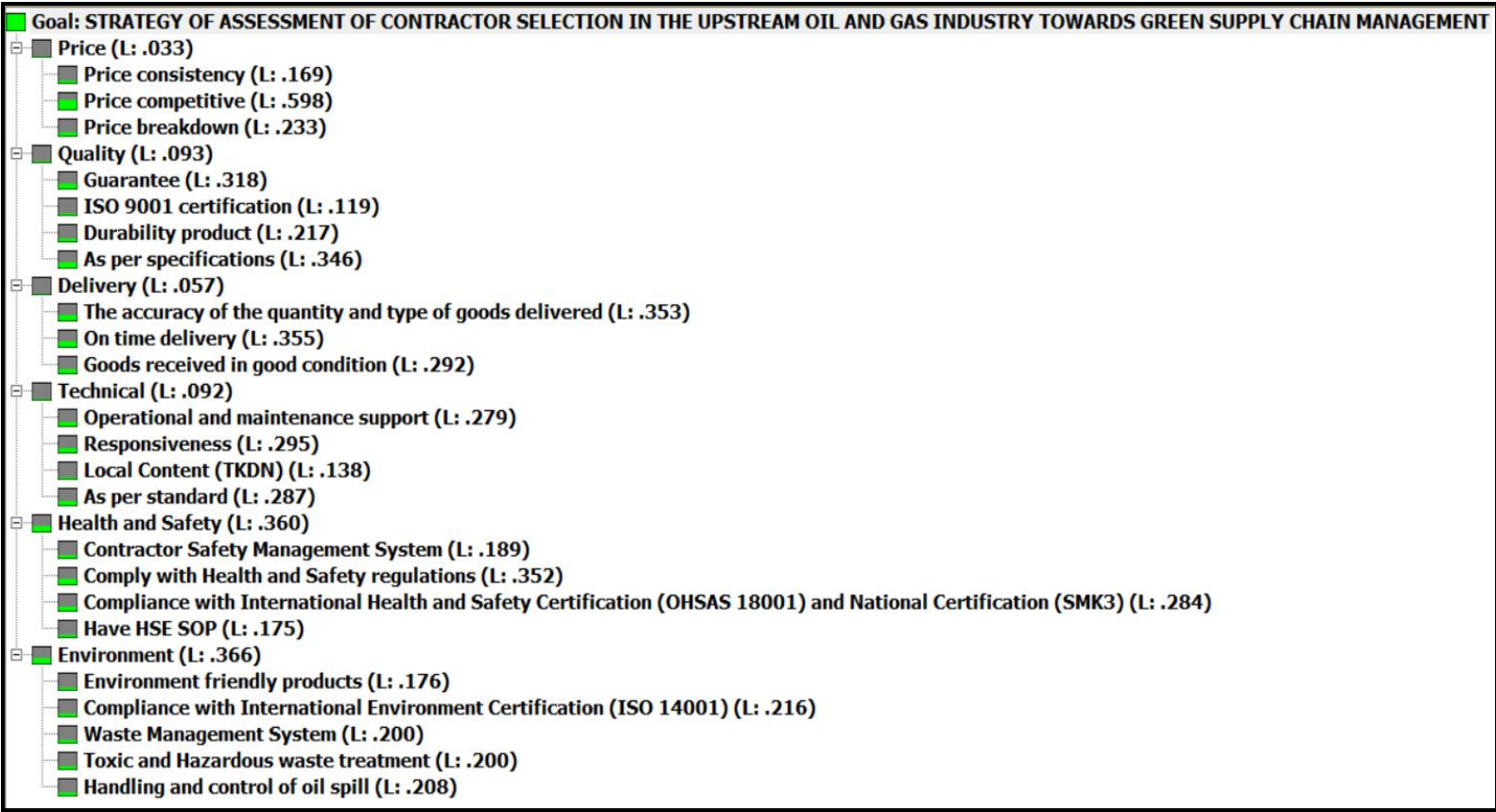

Figure 2. Local and Global Weight Criteria and Sub Criteria (Source: Expert Choice software data processing results)

From the weighting, the final synthesis value is made for the results of local and global weights for the criteria and sub-criteria for the selection of oil and gas contractors towards Green Supply Chain Management.

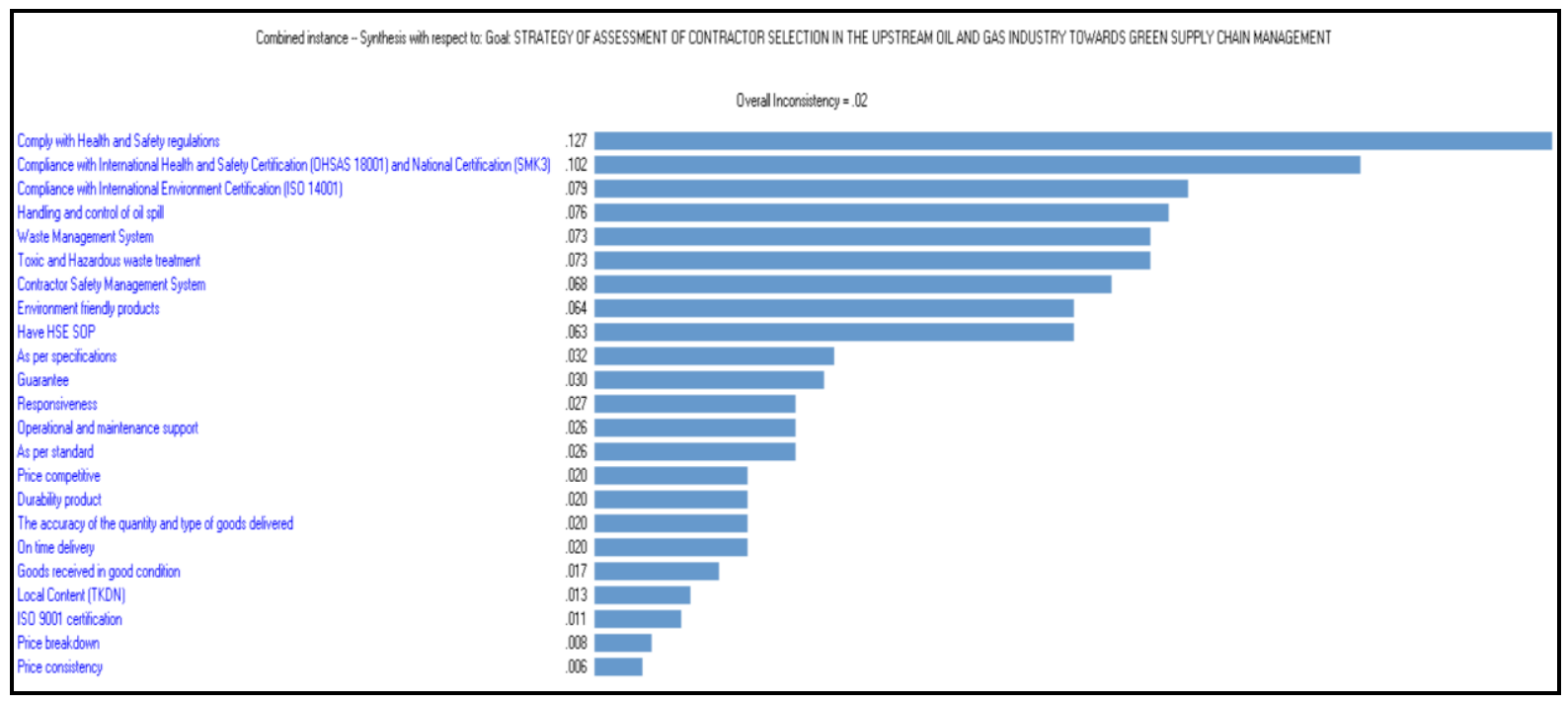

Figure 3. Sequence of global weights for sub criteria (Source: Expert Choice software data processing results)

From the results of multiplication of criteria weights with local weights the subcriteria obtained global weights values from the sub-criteria. For the criteria weights themselves function locally and globally. This is because criteria are the highest level of pairwise comparisons in the decision making hierarchy.

After obtaining the final synthesis value of weighting criteria and sub-criteria, then a decision making hierarchy model is made. The following is the decision making hierarchy 
model in evaluating of oil and gas contractors selection towards Green Supply Chain Management, as shown in Figure 4.

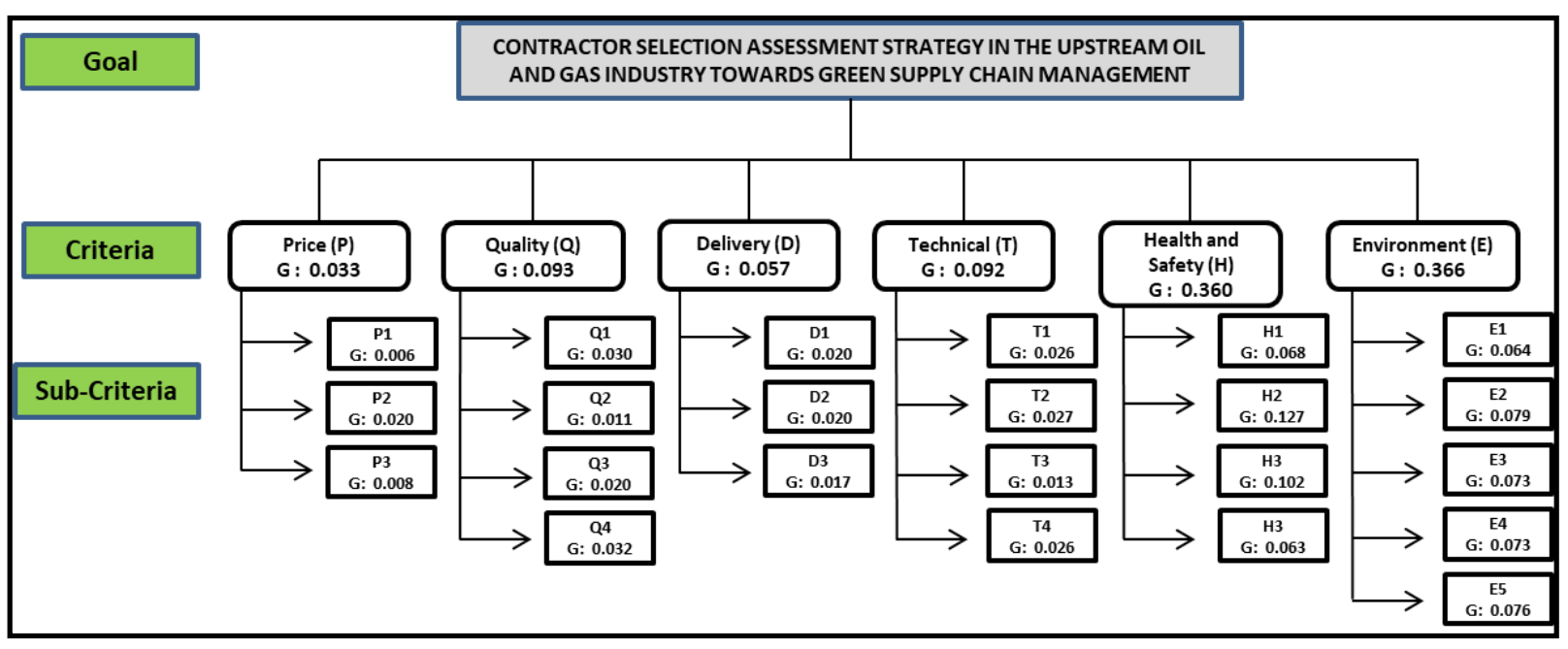

Figure 4. Decision Making Hierarchy Model (Source: Author's data processing results (2020))

\section{Annotation:}

P1 Price consistency

P2 Price competitive

P3 Price breakdown

Q1 Guarantee

Q2 ISO 9001 certification

\section{Q3 Durability product}

Q4 As per specifications

D1 The accuracy of the quantity and type of goods delivered

D2 On time delivery

D3 Goods received in good condition

T1 Operational and maintenance support

T2 Responsiveness
T3 Local Content (TKDN)

T4 As per standard

H1 Contractor Safety Management System

H2 Comply with Health and Safety regulations

H3 Compliance with International Health and Safety Certification (OHSAS 18001) and National Certification (SMK3)

H4 Have HSE SOP

E1 Environment friendly products

E2 Compliance with International Environment Certification (ISO 14001)

E3 Waste management system

E4 Toxic and Hazardous waste treatment

E5 Handling and control of oil spill

\section{CONCLUSION}

Based on the calculation and analysis of the data above, the assessment process for contractor's selection in the upstream oil and gas industry towards Green Supply Chain 
Management contained 6 criteria and 23 sub-criteria that could be used in the assessment process. Environmental Criteria and Health and Safety criteria are the two main criteria that take priority for contractor's selection in the upstream oil and gas industry towards Green Supply Chain Management with a total weighting of more than $50 \%$ of the total weight of the assessment.

The indicators of Environmental Criteria includes (a) Environmental friendly products, (b) Compliance with International Environment Certification (ISO 14001), (c) Waste Management Systems, (d) Toxic and Hazardous Waste Treatment, and (e) Handling and Control of Oil Spill, while the indicators Health and Safety Criteria includes (a) Contractor Safety Management System, (b) Comply with Health and Safety regulations, (c) Compliance with International Health and Safety Certification (OHSAS 18001) and National Certification (SMK3), and (d) have HSE SOP.

The next criteria which includes Quality, Technical, Delivery, and Price are remain to be considered further in the assessment of the contractor's selection in the upstream oil and gas industry towards Green Supply Chain Management so that the spirit of competition between contractors still exist and XYZ company has many options contractor in order to to realize Green Supply Chain Management.

\section{REFERENCES}

[1] Sutawidjaya, A. H., Nawangsari, L. C., \& Suharno. (2017). A Framework Distribution Strategies on Green Supply Chain Management. Seminar Nasional Inovasi Dan Aplikasi Teknologi Di Industri 2017.

[2] Pratiwi, I., MZ, H., \& Aprilyanti, S. (2018). Pemilihan Supplier Terbaik Penyedia Barang Consumable Menggunakan Metode Analytical Hierarchy Process (Studi kasus di Departemen Pengadaan Barang PT. Pusri). Jurnal Manajemen Industri dan Logistik, Vol. 2(2), 147-158.

[3] Handfield, R., \& Nichols, Jr., E. (2002). Supply chain redesign: Transforming supply chains into integrated value systems. New Jersey: Financial Times Prentice Hall.

[4] Luthra, Sunil et. al. (2010). Barriers to Implement Green Supply Chain Management in automobile industry using interpretative Structural Modelling Technique-An Indian Perspective. Journal of Industrial Engineering and Management, 231 - 257.

[5] SKK Migas. (2017). PTK-007 Revisi-IV/PTK/2017, Buku Kedua: Pedoman Pelaksanaan Pengadaan Barang dan Jasa. Jakarta: SKK Migas.

[6] Saaty, T. L. (1980). The Analytical Hierarchy Process. New York: Mc Graw Hill.

[7] Saaty, T. L. (1998). The Analytic Hierarchy Process: Planning, Priority, Setting, Resource Allocation. Ellsworth Ave, Pittsburgh: RWS Publications

[8] SKK Migas. (2018). PTK-005 Revisi-II/PTK/2018, Pedoman Tata Kerja Pengelolaan Kesehatan, Keselamatan Kerja, dan Lindungan Lingkungan Di Kegiatan Usaha Hulu Minyak dan Gas Bumi. Jakarta: SKK Migas.

[9] Budiaji, W. (2013). Skala Pengukuran dan Jumlah Skala. Jurnal Ilmu Pertanian dan Perikanan, Vol. 2 (2), 127-133. 